\title{
Relationship of Gender and Serum Calcium and/or Phosphorus Levels on Admission with the Etiology and Early Prognosis of Hypercalcemia
}

\author{
Başvuru Anındaki Serum Kalsiyum ve/veya Fosfor Düzeyleri ve Cinsiyetin, \\ Hiperkalseminin Etiyolojisi ve Erken Prognozu ile illişkisi
}

\author{
๑ Betül Erişmiş, ๑ Faruk Karandere, ๑ Deniz Yılmaz, @ Mehmet Hurşitoğlu, \\ (1) Abdulbaki Kumbasar
}

University of Health Sciences Turkey, Bakırköy Dr. Sadi Konuk Training of Research Hospital, Clinic of Internal Medicine, Istanbul, Turkey

Abstract

Aim: Hypercalcemia (HCM) is a common clinical problem characterized by a serum corrected calcium (cCa) level of $>10.7 \mathrm{mg} / \mathrm{dL}$. Primary hyperparathyroidism and malignancy are mostly (90\%) involved in the etiology. In this study, we aimed to determine the relationship of cCa and phosphorus $(\mathrm{P})$ levels, $\mathrm{CCa} / \mathrm{P}$ ratio and gender with the etiology of HCM and one-week mortality.

Methods: Records of HCM patients older than 18 years of age who were hospitalized between January 1, 2017 and December 31, 2018 were retrospectively reviewed. Age, gender, cCa and P levels, HCM etiology and one-week survival status of the patients were recorded. Subsequently, the patients were divided into two groups according to whether the etiology of HCM was benign or malignant. Then, the groups were compared statistically in terms of gender, biochemical values and one-week survival.

Results: The median level of serum cCa was found to be significantly higher in males $(p<0.00)$. The frequency of malignancy-associated HCM was higher in males than in females. When the groups were compared, serum CCa and P levels were found to be higher in malignancy-associated group $(p<0.000$ and $p=0.005$, respectively). The one-week mortality rate in all patients was $18.99 \%$. However, surprisingly, the oneweek mortality rate in malignancy-associated HCM was lower than in the other group.

Conclusion: Our study results show that serum cCa and P levels at the time of admission, and gender may help early evaluation of the etiology and/or prognosis of HCM.

Keywords: Hypercalcemia, mortality, calcium, phosphorus, prognosis
Öz

Amaç: Hiperkalsemi (HK), serum düzeltilmiş kalsiyum (dCa) seviyesinin 10,7 mg/dL'nin üzerinde olması ile karakterize yaygın bir klinik sorundur. Etiyolojide çoğunlukla (\%90) primer hiperparatiroidizm ve malignite yer alır. Biz bu çalışmamızla tanı anındaki kalsiyum ve fosfor düzeyleri, $\mathrm{dCa}$ /P oranı ve cinsiyetin, hiperkalsemi etiyolojisi ve 1 . hafta mortalitesi ile ilişkisini saptamayı amaçladık.

Yöntemler: 1 Ocak 2017 ve 31 Aralık 2018 tarihleri arasında hastanemizde yatarak tetkik ve tedavi edilen 18 yaşından büyük hiperkalsemili hastaların kayıtları retrospektif olarak incelendi. Hastaların yaş, cinsiyet, kalsiyum ve fosfor düzeyleri, HK etiyolojisi ve 1.hafta sağkalım durumları kaydedildi. Hastalar HK etiyolojisinin benign ya da malign nedenlere bağlı olmasına göre iki gruba ayrıldı. Gruplar, yaş, cinsiyet, belirtilen biyokimyasal değerler ve ilk hafta sağkalımı açısından istatistiksel olarak karşılaştırıldı.

Bulgular: Serum dCa'nın medyan seviyesi erkeklerde anlamlı olarak daha yüksek tespit edildi $(p<0,00)$. Malignite ile ilişkili HK sıklığı erkeklerde kadınlardan daha fazlaydı. Malign ve benign etiyolojik gruplar karşılaştırıldığında, serum dCa ve $P$ düzeyleri maligniteye bağlı hiperkalsemide daha yüksek saptandı $(p<0,000$ ve 0,005). Tüm hastaların ilk hafta mortalite oranı \%18,99 idi. Ancak şaşırtıcı bir şekilde, malignite ilişkili HK'de 1. hafta ölüm oranı diğer gruptan daha düşüktü.

Sonuç: Çalışma sonuçlarımız, HK ile başvuran hastalarda başvuru anındaki serum dCa ve serum $\mathrm{P}$ düzeyleri ile cinsiyetin, hiperkalseminin etiyolojisi ve/veya prognozunun erken değerlendirilmesine yardımcı olabileceğini göstermektedir.

Anahtar Sözcükler: Hiperkalsemi, mortalite, kalsiyum, fosfor, prognoz
Address for Correspondence/Yazışma Adresi: Betül Erişmiş, University of Health Sciences Turkey, Bakırköy Dr. Sadi Konuk Training of Research Hospital, Clinic of Internal Medicine, istanbul, Turkey

E-mail: betul_erismis@yahoo.com ORCID: orcid.org/0000-0003-2970-2076

Received/Geliş Tarihi: 20 April 2020 Accepted/Kabul Tarihi: 01 November 2020
${ }^{\circ}$ Copyright 2020 by The Medical Bulletin of istanbul Haseki Training and Research Hospital The Medical Bulletin of Haseki published by Galenos Yayınevi. ${ }^{\circledR}$ Telif Hakkı 2020 istanbul Haseki Eğitim ve Araştırma Hastanesi Haseki Tıp Bülteni, Galenos Yayınevi tarafından yayınlanmıştır. 


\section{Introduction}

Hypercalcemia (HCM) is a common clinical problem characterized by a serum calcium level of $>10.7 \mathrm{mg} / \mathrm{dL}$ (>2.6 mmol/L). HCM may be mild [serum calcium <12 $\mathrm{mg} / \mathrm{dL}$ (3 $\mathrm{mmol} / \mathrm{L})$ ], severe [serum calcium $>14 \mathrm{mg} / \mathrm{dL}$ (3.5 mmol/L)], or moderate (in between the above levels). Primary hyperparathyroidism and malignancy account for about $90 \%$ of all cases of $\operatorname{HCM}(1,2)$.

Serum corrected calcium (cCa) level is used in evaluating HCM (2). In a study by Catalano et al. (3) from Italy, it was reported that hypocalcemia was more common in males while HCM did not show a gender difference. Also, unlike hypocalcemia, the incidence of HCM did not show a significant increase over time in the same study. In another study, although HCM was more common in females, malignancy-related HCM was found to be more frequent in males (4). As far as we know, there is no study about gender difference in the etiology of HCM and/or on the 1st week mortality of HCM in Turkey and the neighboring countries. To the best of our knowledge, there is also no study about the relationship of admission serum CCa and serum P levels (and CCa/P ratio) with the type of HCM (benign or malignancyrelated) and/or with 1 st week outcomes.

\section{Methods}

This retrospective study was approved by University of Health Sciences Turkey, Bakırköy Dr. Sadi Konuk Training and Research Hospital Ethics Committee (decision no: 2019-1902, date: 30.09.2019). This study was done in accordance with the RECORD Reporting Guidelines (5). Records of patients older than 18 years with HCM who were admitted to University of Health Sciences Turkey, Bakırköy Dr. Sadi Konuk Training and Research Hospital between 1st January 2017 and 31st December 2018 were retrospectively reviewed. The patients were divided into two groups:

Group 1: consisted of patients with malignancyassociated HCM ( $n=113)$.

Group 2: non-malignancy (benign)-related HCM (due to primary, secondary or tertiary hyperparathyroidism, drug-induced vitamin $D$ intoxication, granulomatous or other endocrinological causes) ( $n=98)$.

Inclusion criteria:

1. Age $\geq 18$ years (both groups),

2. Availability of admission serum cCa, and serum $P$ levels (both groups),

3. Availability of 1 st week mortality and outcome records (both groups),

Exclusion criteria:

1. Temporary HCM

2. Uncertainty of the etiology of HCM (both groups)
3. Insufficient patient records (both groups)

Records of 230 patients were reviewed. Nineteen patients were excluded due to presence of at least one of the above-mentioned exclusion criteria. Thus, final analysis was done with a total of 211 hypercalcemic patients. The primary aim of this study was to compare age, sex, serum $\mathrm{CCa}$ and $\mathrm{P}$ levels, $\mathrm{CCa} / \mathrm{P}$ ratio between the two groups. A secondary aim of the study was to investigate the relationship of these parameters with the 1 st week outcomes of the patients.

\section{Data Availability}

Data are available for researchers (for research purposes only) on request by contacting the corresponding author.

\section{Statistical Analysis}

Statistical analyses were performed using the SPSS 22.0 statistical package for Windows. Description of data was expressed by mean, standard deviation, median and interquartile range, as appropriate. The distribution of variables was analyzed using the Kolmogorov-Smirnov test. For a comparison of variables of a normal distribution, the independent samples t-test was used and the Mann-Whitney $U$ test was used for the comparison of variables with non-normal distribution. Pearson's correlation coefficient and its nonparametric equivalent Spearman's correlation coefficient were also used for evaluation of the correlation between quantitative variables. A p value of less than 0.05 was considered statistically significant.

\section{Results}

The mean age of the patients was $64.86 \pm 13.92$ years. The female to male ratio was 114/97. The median serum cCa level in males was significantly higher than in females $(p=<0.001)$. On the other hand, there was no significant difference in the median values of age, $\mathrm{P}$ and $\mathrm{CCa} / \mathrm{P}$ ratio between the genders ( $p>0.05$ for all) (Table 1). Comparing the patients according to malignant (group 1) or benign (group 2) etiology, serum $c C a$, and $P$ levels were higher in malignancy-related HCM group $(p=<0.0001$ and $p=0.005$, respectively). However, age, and $\mathrm{CCa} / \mathrm{P}$ ratio showed no significant difference between the groups $(p<0.05)$ (Table 2 ). Comparison of males and females separately showed that serum cCa was higher in both females and males of group 1 (in comparison to group 2 females and males) ( $p \leq 0.0001$ and $p=0.017$, respectively). Serum $P$ level and $\mathrm{CCa} / \mathrm{P}$ ratio were significantly higher in females (but not in males) in group 1 ( $p=0.002$ and $p=0.048$, respectively). There was no significant difference in age between genders in both groups ( $p \leq 0.05)$ (Table 3$)$. Of the total 113 patients with malignancy-related HCM, females [44 (39\%)] were less than males $[69(61 \%)]\left(\chi^{2}=5.53, p=0.019\right)$. Also, only 
three of the 113 malignancy-related HCM patients died in the $1^{\text {st }}$ week $\left(\chi^{2}=101.32, p \leq 0.0001\right)$.

Comparing these 211 hypercalcemic patients for $1^{\text {st }}$ week mortality, nine (18.99\%) died at the end of the 1 st week follow-up. Comparison of the parameters of those who died with those who survived at the end of the 1 st week is shown in Table 4. Serum P levels and cCa/P ratio were higher in patients who died than in survived patients ( $p=0.038$ and $p=0.046$, respectively). Although the mean age and serum cCa level in the dead patients were higher than in those who survived, it did not reach a statistical significance $(p>0.05)$. Eight of these nine patients were male $\left(\chi^{2}=5.44, p \leq 0.020\right)$. Further analysis of the survived 202 patients showed that 37 (18.32\%) of them were admitted to an intensive care unit (ICU) during the $1^{\text {st }}$ week of hospitalization. Comparison of data of survived patients who did and did not require ICU admission showed that only serum cCa levels were significantly higher in patients requiring ICU [14.5 (12.718.30) vs $13.10(12.0-20.0) \mathrm{mg} / \mathrm{dL}, \mathrm{p}<0.0001]$. Also,

\begin{tabular}{|c|c|c|c|c|c|c|}
\hline \multicolumn{3}{|c|}{ Gender } & Age & $\mathrm{cCa}$ & $\mathrm{Ca} / \mathrm{P}$ ratio & Phosphorus \\
\hline \multirow{4}{*}{ Female } & \multirow{2}{*}{$\mathrm{N}$} & Valid & 114 & 114 & 96 & 96 \\
\hline & & Missing & 0 & 0 & 18 & 18 \\
\hline & \multicolumn{2}{|c|}{ Mean (SD) } & $65.01(13.99)$ & $13.42(1.38)$ & $5.42(2.47)$ & $2.94(1.26)$ \\
\hline & \multicolumn{2}{|c|}{ Median (min-max) } & $66.00(18.00-91.00)$ & $13.08(12.00-19.30)$ & $5.03(2.16-13.7)$ & $2.50(1.00-6.00)$ \\
\hline \multirow{4}{*}{ Male } & \multirow{2}{*}{ N } & Valid & 97 & 97 & 70 & 70 \\
\hline & & Missing & 0 & 0 & 27 & 27 \\
\hline & \multicolumn{2}{|c|}{ Mean (SD) } & $64.68(13.55)$ & 14.49 (1.75) & $5.38(2.43)$ & $3.20(1.56)$ \\
\hline & \multicolumn{2}{|c|}{ Median (min-max) } & $66.00(20.00-97.00)$ & $14.10(12.10-20.40)$ & $4.97(1.94-13.10)$ & $2.80(1.00-7.60)$ \\
\hline Total & \multicolumn{2}{|c|}{$\begin{array}{l}\mathrm{N} \\
\text { Mean (SD) } \\
\text { Median (min-max) }\end{array}$} & $\begin{array}{l}211 \\
64.86(13.92) \\
66.00(18.00-97.00)\end{array}$ & $\begin{array}{l}211 \\
13.91(1.65) \\
13.50(12.00-20.40)\end{array}$ & $\begin{array}{l}166 \\
5.40(2.44) \\
4.98(1.94-13.70)\end{array}$ & $\begin{array}{l}166 \\
3.05(1.39) \\
2.74(1.00-7.60)\end{array}$ \\
\hline \multicolumn{3}{|l|}{$P$ value } & $>0.05$ & $<0.00^{*}$ & $>0.05$ & $>0.05$ \\
\hline \multicolumn{7}{|c|}{$\begin{array}{l}\text { All data are non normally distributed. } \\
\text { NS: Not significant, SD: Standard deviation } \\
\text { cCa: corrected calcium, min: Minimum, max: }\end{array}$} \\
\hline
\end{tabular}

\begin{tabular}{|c|c|c|c|c|c|}
\hline \multicolumn{2}{|l|}{ Etiology } & \multirow{2}{*}{$\begin{array}{l}\text { Age } \\
65.13(12.21)\end{array}$} & \multirow{2}{*}{$\frac{\mathbf{c C a}}{14.53(1.69)}$} & \multirow{2}{*}{$\frac{\mathrm{Ca} / \mathrm{P} \text { ratio }}{5.35(2.70)}$} & \multirow{2}{*}{$\begin{array}{l}\text { Phosphorus } \\
3.30(1.51)\end{array}$} \\
\hline Group 1 & Mean (SD) & & & & \\
\hline$(n=113)$ & Median (min-max) & $66.00(20.00-93.00)$ & $14.10(12.20-20.40)$ & $4.57(2.13-13.70)$ & $3.20(1.00-7.60)$ \\
\hline \multirow{2}{*}{$\begin{array}{l}\text { Group } 2 \\
(n=98)\end{array}$} & Mean (SD) & $64.55(15.41)$ & $13.20(1.28)$ & $5.46(2.17)$ & $2.79(1.22)$ \\
\hline & Median (min-max) & $6.00(18.00-97.00)$ & $12.80(12.00-16.80)$ & $5.34(1.94-13.10)$ & $2.41(1.00-6.50)$ \\
\hline \multicolumn{2}{|l|}{$P$ value } & NS & $<0.000$ & NS & 0.005 \\
\hline
\end{tabular}

\begin{tabular}{|c|c|c|c|c|c|c|}
\hline Group & & Gender & Age & $\mathrm{cCa}$ & $\mathrm{cCa} / \mathrm{P}$ ratio & Phosphorus \\
\hline \multirow{4}{*}{$\begin{array}{l}\text { Group } 1 \\
\text { (Malignant } \\
\text { etiology) }\end{array}$} & \multirow{2}{*}{$F(n=44)$} & Mean (SD) & $64.04(12.45)$ & $14.22(1.55)$ & $5.25(2.98)$ & $3.37(1.43)$ \\
\hline & & Median (min-max) & $64.50(38.00-86.00)$ & $13.90(12.20-19.30)$ & $4.40(2.16-13.70)$ & $3.40(1.00-6.80$ \\
\hline & \multirow{2}{*}{$M(n=69)$} & Mean (SD) & $65.82(12.09)$ & $14.73(1,75)$ & $5.43(2.49)$ & $3.25(1.58)$ \\
\hline & & Median (min-max) & $67.00(20.00-93.00)$ & $14.50(12.30-20.40)$ & $4.70(2.13-11.73)$ & $3.10(1.10-7.60)$ \\
\hline \multirow{4}{*}{$\begin{array}{l}\text { Group } 2 \\
\text { (Benign } \\
\text { etiology) }\end{array}$} & \multirow{2}{*}{$F(n=70)$} & Mean (SD) & $65.62(14.94)$ & $12.92(0.99)$ & $5.52(2.11)$ & $2.67(1.06)$ \\
\hline & & Median (min-max) & $66.50(18.00-91.00)$ & $12.70(12.00-16.80)$ & $5.24(2.22-12.20)$ & $2.42(1.00-5.80)$ \\
\hline & \multirow{2}{*}{$M(n=82)$} & Mean (SD) & $61.85(16.51)$ & $13.90(1.63)$ & $5.28(2.33)$ & $3.10(1.55)$ \\
\hline & & Median (min-max) & $62.50(29.00-97.00)$ & $13.25(12.10-16.80)$ & $5.40(1.94-13.10)$ & $2.30(1.00-6.50)$ \\
\hline \multicolumn{3}{|l|}{$\mathrm{P}$ value } & NSF, NSM & $<0.000^{F}, 0.017 \mathrm{M}$ & $0.002^{F}, \mathrm{NSM}$ & $0.048 \mathrm{~F}, \mathrm{NSM}$ \\
\hline
\end{tabular}


only 11 (29.73\%) of these 37 ICU-requiring patients were female $\left(\chi^{2}=6.081, p \leq 0.014\right)$.

Spearman's correlation coefficient showed that serum $\mathrm{cCa}$ and serum P levels were positively correlated with malignancy-related HCM. However, there was a negative correlation between serum $\mathrm{P}$ levels and the $1^{\text {st }}$ week outcomes (see Table 5).

\section{Discussion}

While primary hyperparathyroidism and malignancy account for $80-90 \%$ of all cases of HCM, the differential diagnosis has expanded to over 25 separate disease states. Among the outpatient population, primary hyperparathyroidism is the most common cause of $\mathrm{HCM}$, but malignancy accounts for approximately $65 \%$ of hospitalized patients (6). Regardless of the etiology, the signs and symptoms of HCM are similar, but there are several clinical features that may help differentiate the etiology of HCM. Measurement of parathyroid hormone (PTH) and/or PTH-related protein (PTHrP) levels help identify the cause of HCM (7). However, these tests are not routine or early tests in the management of HCM. Also performing these tests needs somewhat more time than serum cCa and P tests. Additionally, PTHrP test is even not routine in most of the centers (at least in developing and/or in underdeveloped countries). HCM may be a lifethreatening condition and may require urgent treatment and/or ICU admission. Thus, early evaluation (from etiology point of view) and planning further diagnostic studies and management are of paramount importance (8).

In our study, both serum $\mathrm{CCa}$ and serum $\mathrm{P}$ levels were higher in malignancy-related $\mathrm{HCM}$ (in comparison

\begin{tabular}{|c|c|c|c|c|c|c|}
\hline Groups & Gender & & Age & $\mathrm{cCa}$ & $\mathrm{Ca} / \mathrm{P}$ ratio & Phosphorus \\
\hline \multirow{6}{*}{$\begin{array}{l}\text { Survived at } 1^{\text {st }} \\
\text { week }\end{array}$} & \multirow{2}{*}{$F(n=102)$} & Mean (SD) & $65.27(14.22)$ & $13.30(1.34)$ & $5.27(2.25)$ & $2.97(1.26)$ \\
\hline & & Median (min-max) & $67.00(18.00-91.00)$ & $13.00(12.00-19.30)$ & $4.97(2.16-12.20)$ & $2.50(1.00-6.80)$ \\
\hline & \multirow{2}{*}{$M(n=63)$} & Mean (SD) & $63.25(12.63)$ & $14.21(1.74)$ & $5.61(2.34)$ & $3.02(1.50)$ \\
\hline & & Median (min-max) & $64.00(29.00-93.00)$ & $13.70(12.10-20.40)$ & $5.23(1.94-11.73)$ & $2.70(1.10-7.20)$ \\
\hline & \multirow{2}{*}{ Total } & Mean (SD) & $64.86(13.76)$ & 13.91(1.65) & $5.40(2.44)$ & $3.05(1.39)$ \\
\hline & & Median (min-max) & $66.00(18.00-97.00)$ & $13.50(12.00-20.40)$ & $4.98(1.94-13.70)$ & $2.74(1.00-7.60)$ \\
\hline \multirow{6}{*}{$\begin{array}{l}\text { Non-survived at } \\
1^{\text {st }} \text { week }\end{array}$} & \multirow{2}{*}{$F(n=1)$} & Mean (SD) & 55.00 & 15.70 & 4.48 & 3.50 \\
\hline & & Median (min-max) & 55.00 & 15.70 & 4.48 & 3.50 \\
\hline & \multirow{2}{*}{$M(n=8)$} & Mean (SD) & $72.50(14.55)$ & $14.48(1.95)$ & $3.77(1.76)$ & $4.25(1.59)$ \\
\hline & & Median (min-max) & $74.50(51.00-97.00)$ & $14.35(12.10-16.80)$ & $3.33(2.51-7.22)$ & $4.40(1.80-6,50)$ \\
\hline & \multirow{2}{*}{ Total } & Mean (SD) & $70.55(14.80)$ & $14.62(1.87)$ & $3.87(1.63)$ & $4.14(1.48)$ \\
\hline & & Median (min-max) & $73.00(51.00-97.00)$ & $15.70(12.10-16.80)$ & $3.66(2.51-7.22)$ & $4,30(1,80-6.50)$ \\
\hline \multicolumn{3}{|l|}{$P$ value } & NST & NST & $0.046^{\top}$ & $0.038^{\top}$ \\
\hline
\end{tabular}

Table 5. Spearman's correlation analysis results

\begin{tabular}{|c|c|c|c|c|c|c|c|}
\hline & & & $\mathrm{cCa}$ & $\mathbf{P}$ & Etiology & $\mathrm{cCa} /$ Pratio & $\begin{array}{l}\text { Mortalite } \\
\text { (1 } 1^{\text {st }} \text { week) }\end{array}$ \\
\hline \multirow{10}{*}{ Spearman's rho } & \multirow{2}{*}{ cCA } & Correlation coefficient & 1.000 & $0.403^{* *}$ & 0.471 ** & $-0.186^{\star}$ & -0.074 \\
\hline & & Sig. (2-tailed) & - & 0.000 & 0.000 & 0.016 & 0.282 \\
\hline & \multirow{2}{*}{$P$} & Correlation coefficient & $0.403^{* *}$ & 1.000 & $0.218^{* *}$ & $-0.966^{* *}$ & $-0.161^{*}$ \\
\hline & & Sig. (2-tailed) & 0.000 & - & 0.005 & 0.000 & 0.038 \\
\hline & \multirow{2}{*}{ Etiology } & Correlation coefficient & 0.471 ** & $0.218^{* *}$ & 1.000 & -0.122 & 0.086 \\
\hline & & Sig. (2-tailed) & 0.000 & 0.005 & - & 0.119 & 0.216 \\
\hline & \multirow{2}{*}{$\mathrm{cCa} / \mathrm{P}$ ratio } & Correlation coefficient & $-0.186^{*}$ & $-0.966^{* *}$ & -0.122 & 1.000 & $0.155^{*}$ \\
\hline & & Sig. (2-tailed) & 0.016 & 0.000 & 0.119 & - & 0.046 \\
\hline & \multirow{2}{*}{ Mortality (1st week) } & Correlation coefficient & -0.074 & $-0.161^{*}$ & 0.086 & $0.155^{*}$ & 1.000 \\
\hline & & Sig. (2-tailed) & 0.282 & 0.038 & 0.216 & 0.046 & . \\
\hline
\end{tabular}


to benign etiologies associated HCM) in all patients with no difference between males and females. Another important finding in our patient series is that the frequency of malignancy-related HCM was more common in males than females (Table 3). Correlation analysis also showed a significant positive correlation between these parameters and the presence of malignancy-related HCM (Table 5).

Previous studies showed that life expectancy was poor in cancer-associated HCM even in patients who were actively treated. Ralston et al. (9) showed that the availability of specific anticancer treatment was an important prognostic indicator; the median survival was 30 days who did not receive any specific anticancer treatment. In our study, the 1 st week mortality rate in our inpatients with HCM was $18.99 \%$. Surprisingly, the 1 st week death rate in patients with malignancy-related HCM was lower than in the other group.

Also, the male/female ratio of death was higher in all patients in the 1 st week. Although serum $\mathrm{cCa}$ levels showed no significant difference, serum $\mathrm{P}$ level and $\mathrm{cCa} / \mathrm{P}$ ratio were higher in patients who died than in those who survived. In the survived ones, the number of patient who required intensive care after $1^{\text {st }}$ week was higher in men than in women. Therefore, our study findings showed that serum $\mathrm{cCa}$, and serum $\mathrm{P}$ could help predict the etiology of HCM. On the other hand, gender could be useful in predicting the etiology and 1 st week mortality and need for ICU as well.

\section{Study Limitations}

One of the limitations of our study is its retrospective nature. PTHrP is not in routine use in our center. So, this parameter was not used in classifying HCM patients. Additionally, uncertain cases (from etiology point of view) were excluded from the final analysis (of 230 patients only 211 cases were included in the final analysis).

\section{Conclusion}

Our study results show that early admission data (gender, serum cCa level, and serum P level) may help early evaluation of the etiology and/or early prognosis of HCM. Further studies are needed in this field.

\section{Authorship Contributions}

Concept: B.E., F.K., D.Y., M.H., A.K. Design: B.E., M.H., A.K. Data Collection or Processing: B.E., F.K., D.Y. Analysis or Interpretation: B.E., F.K., M.H., A.K. Literature Search: B.E., F.K., D.Y., M.H. Writing: B.E., M.H.

Conflict of Interest: No conflict of interest was declared by the authors.

Financial Disclosure: The authors declared that this study received no financial support.

\section{References}

1. Shane E. Clinical manifestations of hypercalcemia UpToDate. (cited 2020 Jan 15). Available from: https:// www.uptodate.com/contents/clinical-manifestations-of hypercalcemia? search=hypercalcemia\&source=search_ result\&selectedTitle=3 150\&usage_type=default\&display_ rank=3

2. Vakiti A, Mewawalla P. Malignancy-Related Hypercalcemia [Internet]. StatPearls. StatPearls Publishing; 2019 (cited 2020 Jan 15).

3. Catalano A, Chilà D, Bellone F, et al. Incidence of hypocalcemia and hypercalcemia in hospitalized patients: Is it changing? J Clin Transl Endocrinol 2018;13:9-13.

4. Hamilton F, Carroll R, Hamilton W, Salisbury C. The risk of cancer in primary care patients with hypercalcaemia: a cohort study using electronic records. Br J Cancer 2014;111:1410-2.

5. Benchimol El, Smeeth L, Guttmann A, et al. The REporting of studies conducted using observational routinelycollected health Data (RECORD) Statement. PLOS Med 2015;12:e1001885.

6. Lafferty FW. Differential diagnosis of hypercalcemia. J Bone Miner Res 1991;6(Suppl 2):S51-9.

7. Minisola S, Pepe J, Piemonte S, Cipriani C. The diagnosis and management of hypercalcaemia. BMJ 2015;350:h2723.

8. Mousseaux C, Dupont A, Rafat C, et al. Epidemiology, clinical features, and management of severe hypercalcemia in critically ill patients. Ann Intensive Care 2019;9:133.

9. Ralston SH, Gallacher SJ, Patel U, Campbell J, Boyle IT. Cancer-associated hypercalcemia: morbidity and mortality. Clinical experience in 126 treated patients. Ann Intern Med 1990;112:499-504. 